American Journal of Economics and Business Administration 1 (2) 47-56, 2009

ISSN 1945-5488

(C) 2009 Science Publications

\title{
Determinants of Outward Foreign Direct Investments from Small Island Developing States
}

\author{
Densil A. Williams \\ Department of Management Studies, \\ University of the West Indies, Mona, Jamaica West Indies
}

\begin{abstract}
Problem statement: Although there is a burgeoning literature on the rise of Multinational Enterprises (MNEs) from developing economies, comparatively less work exists on MNEs from small, developing economies. Given the precipitous rise in the level of outward foreign direct investments from small, economies, it is still not clear in the academic literature and for policy purposes, those factors in the home environment which influence the rise of these multinational enterprises from these smaller economies. This study aimed to determine those economic and social factors at home that are most important in influencing the level of outward foreign direct investments from Small, Island Developing States (SIDS)? Approach: To achieve the research objective, a literature review was first conducted to identify those factors that were commonly cited as critical for motivating domestic firms to be engaged in outward foreign direct investments. To test which of these factors were most influential in the case of small island developing economies, secondary data on each of the variables identified from the literature were collected from sources such as: International financial statistics, the world investment report, the world economic outlook, transparency international and, the world development indicators. These data were used to build a 5 year panel dataset. The panel data set consisted of 5 years of data from 1998-2002, for 15 small economies which are defined as SIDS by the United Nations classifications. These data were analyzed using the multivariate regression model. The results from the model were used to determine which factors was most influential in motivating domestic firms to get involved in outward foreign direct investments. Results: The results revealed that the level of corruption at home $(p=0.01)$, the per capita income $(p=0.00)$ and, level of economic growth at home $(\mathrm{p}=0.00)$ were most influential in motivating domestic firms to be involved in outward FDI from small island developing states. These findings reflected that both economic and social factors were important in influencing the level of outward FDI from SIDS. Conclusion: These results indicated that if policy makers in SIDS want to encourage more domestic firms to get engaged in outward foreign direct investments, they needed to put policies in place that will grow the local economy. For business practitioners, the results indicated that there will be an increased need for more strategic thinking because more domestic firms will have to be engaged in international business if they are to survive the high level of competition in the small markets in small economies.
\end{abstract}

Key words: Outward foreign direct investments, small island developing states, panel data, multivariate regression

\section{INTRODUCTION}

The arguments in classical economic theory would suggest that outward Foreign Direct Investment (FDI) from $\operatorname{SIDS}^{[27]}$ should not exist. On the basis of these arguments, the directionality of international trade flow should be from developed to developing countries because of the efficiency and sophisticated nature of the goods, capital and labor market in the developed world. Indeed, multinational firms will face greater uncertainty in operating in the host country compared to local firms ${ }^{[16]}$, therefore, they have to possess a monopolistic advantage over local firms in order to survive. This advantage, it is argued, will be derived from its operation in large, developed economies with advanced technology, a large pool of professional and technical workers and, large scale production of technically complex and differentiated goods. The current world of FDI does not show this picture. The domination of North to South ${ }^{[27]}$ flow seems to be rapidly disappearing ${ }^{[4,21]}$. Today, the directionality of investments is changing, with an increasing number of FDIs coming from developing or transition economies. 
The rise in multinational enterprises from the developing world over the last two decades has attracted some attention in the academic literature $^{[12,14,15,22]}$. This literature however, focuses extensively on the rise of multinational enterprises from large, developing economies such as China ${ }^{[1]}$, Eastern Europe $^{[12]}$, India ${ }^{[2]}$ and Latin America ${ }^{[24]}$. Very little is written about the rise of multinationals from small, open developing economies, like those in the Caribbean. This gives the impression that multinationals are not emerging from these geographical locations. However, empirical evidence suggests that firms from these economies are setting up direct investments in both developed and developing countries $^{[21]}$. For example, Grace Kennedy of Jamaica, one of the leading conglomerates in the Caribbean recently acquired SunJuice in the UK to produce and sell its food products in the European Market; Jamaica Producers' Group, another Jamaican enterprise, acquired Serious Foods in the UK through direct investment. Also, Angostura of Trinidad and Tobago, a large producer of alcoholic beverages has acquired the largest beverage producer in Jamaica, Lascelles deMercado. These are merely some of the examples of direct investments coming from small, developing economies.

Increased outward investments bring positive externalities to the home market ${ }^{[16]}$. Therefore, to encourage increased levels of foreign direct investments from smaller economies, it is important for government policymakers and managers at the firm level to understand those country level factors in the home market which influence these investments. This will help to ensure that the correct policies are put in place to enhance the increased outflow of investments from these economies.

Studies on outward foreign direct investments from developing economies generally focus on factors in the host market that determine whether firms choose direct investment or other entry modes such as exporting ${ }^{[6,8,24]}$. However, these studies fail to recognize that home market conditions are important determinants of outward FDI as well. Indeed, Navaretti and Venables ${ }^{[16]}$ correctly assert that: "Relative market size of home and host, matters for FDI". They argue that similarity in home and host country GDP has a positive impact on the activity of the multinational enterprise. Further, multinational enterprises tend to replace national exporting firms with multinational firms when national markets are similar. Clearly, there is an incentive to encourage outward foreign direct investment. However, the factors which influence this process in small, open, developing economies are still not well explored.
Since our knowledge of factors in the home market which influence outward investments is limited, especially as it relates to small economies, this study will try to extend the empirical literature in this area by focusing on those social and economic factors in a group of small economies classified by the United Nations as SIDS. The research will investigate the question:

What economic and social factors in the home market are important in influencing the level of outward foreign direct investments from SIDS? This study will make an important contribution to the extant literature because it focuses on small, developing economies, a rarity in this area of work. Outward foreign direct investments from small economies are not a prominent feature in the international business literature up to now.

To shed light on the research issue, the remainder of the study is organized as follows: The next section will present a discussion on the benefits of outward foreign direct investments to a country. After this discussion, the study then looks at the extant theoretical literature and summarizes the arguments put forward to explain outward FDIs, especially as they relate to developing economies. Following this discussion, the article then looks at the research method and presents the results from the analysis of the data. The paper ends with a discussion and some concluding remarks on the subject.

Benefits of outward FDIs to home countries: When national firms make the decision to set up subsidiaries in foreign markets, this raises debates at home about job losses, skills transfer, decline in productivity among other things. The concern is whether the outward investment by national firms strengthens or weakens the remaining economic activities at home. The immediate reaction to outward investment is that it causes production and employment that would have taken place in the home country to take place abroad. However, the evidence on this claim is mixed ${ }^{[16]}$. Still, it appears that the majority of the arguments seem to fall on the positive side (ibid). That is, outward foreign direct investments generally strengthen economic activities at home.

Outward foreign direct investment will impact on home country's output and employment positively or negatively depending on whether or not the investment is a complement or a substitute. If outward investment is done for firms to gain some cost savings in production, this may translate into stronger operations in the home market as the firm becomes more profitable 
due to reduction in production costs. Further, if the firm invests overseas in order to gain some savings in distributing its product to these overseas markets, this may result in increased output at home. If foreign production is complementary to home production, it means that the foreign subsidiary will be using inputs from home to produce it outputs abroad. This will result in an increase in domestic output. In this regard, the greater the number of foreign plants the greater will be the level of output in the home market. The logical deduction from this argument is that, if foreign production is complementary to home production, output at home will rise and employment will also rise directly or indirectly.

Investing abroad can also result in massive technology transfers for home country firms and thus improve the competitiveness of the home economy. Foreign subsidiaries can become an effective channel for transferring technological knowledge to home, especially if they are located in an area with a high intensity of high-tech activities ${ }^{[22]}$. The subsidiaries in these locations can have positive spillovers for home. There can be movement of employees from subsidiaries to national firms at home. Further, if subsidiaries use inputs from home for their production process, this may result in improved infrastructure at home and may also lead to improved demand conditions in the home market. Indeed, the quality of demand conditions in the home market is seen as an important indicator of national competitiveness for a country ${ }^{[18]}$. Clearly, outward FDI is an important source for improved national competitiveness.

The evidence regarding the impact of outward investment on skill intensity and employment in the home economy is biased towards a positive relationship ${ }^{[16]}$. As argued before, if output at home increases as a result of outward investments, ceteris paribus, employment at home should increase as well. Further, researchers have shown that the employment dynamics of firms that invest abroad do not differ from those that remain local ${ }^{[17]}$. The implication is that even if employment declines in firms that open foreign subsidiaries, the decline is not larger and in some cases smaller than what it would have been if the firms did not invest abroad. Possibly, if the firm had not invested abroad, especially if the investment is vertical ${ }^{[16]}$, the next best alternative would have been to go out of business. The implication of this action for employment is clear. Foreign investments will also impact on the skill intensity at home as reflected in the way things are produced in the domestic market.

Outward foreign direct investment can have an impact on the composition of home employment between skilled and un-skilled labor. Researchers have argued that the relocation of activities may change the division of labor in the multinational firm leading for example, to a concentration of skilled-labor intensive activities at home ${ }^{[5]}$. Further, if the relocation leads to a more efficient use of resources, efficiency and profits at home may increase. It may also result in the economy becoming highly specialized in one type of production over the other. For example, if the relocation leads to more skilled-labor remaining at home, then the home economy will become more specialized in production of high quality labor intensive goods and services. This is akin to the classical Hecksher-Ohlin (H-O) prediction $^{[13]}$.

The above discussion shows that foreign direct investments whether inward or outward, are good for an economy. The benefits from direct investments to the host economy is well recorded ${ }^{[26,27]}$. However, the benefits of direct foreign investments are not unidirectional, the home countries also benefit. Therefore, policymakers in small, developing economies should not be fearful when there is an increase in outward foreign direct investments from their economies. They should embrace these investments and put policies in place to encourage firms to invest abroad. However, in order to design effective policies, policymakers will have to know what factors in the home environment motivate these investments. This will prevent them from providing inappropriate or incorrect stimuli to firms in order to encourage more outward foreign direct investments.

Trade and multinational theories: With the phenomenal rise in the levels of outward investment from developing economies, scholars interested in this field of work have been trying to identify the rationale for this increase. It appears that traditional theories of trade and the multinational are unable to provide fruitful insights into this new phenomenon ${ }^{[12]}$. For example, traditional trade theories of comparative advantage and factor endowment do not give the impression that multinationals can emerge from the developing world. They posit that the movement of capital should be from locations that are more efficient in the use of resources to those that are less efficient. Therefore, capital will gain a higher return on investment. The implicit assumption is that efficiency in the use of resources only occurs in the developed economies where technology, skill levels, economies of scale and product differentiation are more advanced. Traditional H-O theory for example, would argue that under perfect competition, developing countries should specialize in the production of labor 
intensive goods. Since labor is cheap in these countries, there is no incentive for firms to consider vertical foreign direct investment. Further, since their marketing and product differentiation are less sophisticated than those in developed markets, the need for horizontal foreign direct investment (i.e., direct investments aimed at supplying a market through foreign affiliates) will not arise. This type of investment will be considered when the cost of exporting is too high or the firm wants to jump some non-tariff barriers to get into a foreign market. The firms from these locations can export the labor intensive goods to foreign markets. This sort of static interpretation of trade by conventional trade theory will not lead to fruitful predictions about the rise of outward foreign direct investments from developing economies, especially small, developing economies.

On the other hand, theories of the multinational ${ }^{[9,11]}$ are based on the assumption that multinationals exist because they possess monopolistic advantages. These advantages serve as barriers to entry for other firms and therefore allow multinationals to operate profitably abroad. The advantages are generally derived from technological intensity and advanced marketing which allow the firm to differentiate itself from others. It appears that it is this differentiation that has resulted in the increased level of direct investments from developed countries. The possibility of this technological intensity and advanced marketing occurring in developing countries is far fetched to many multinational theorists. Therefore, they, along with traditional trade theorists; do not predict the rise of multinational firms from the developing world. However, the extant reality is that there is an increased level of outward foreign direct investment from the developing world. The multinational theories, although limited in some respects, do provide some insights into this phenomenon.

Multinationals from developing countries- new multinationals $^{[22]}$ must possess some monopolistic advantages as well. These advantages must lie somewhere in the edge they have built up in widely diffused technologies, special knowledge of marketing or special managerial or other skills ${ }^{[15]}$. Indeed, it is possible that there are certain conditions ${ }^{[15]}$ under which firms operating with lower levels of technology and managerial skills; can gain monopolistic advantages which are exploitable in foreign markets. For example, they can make products that are specific to conditions in other developing countries thus meeting the demand for specific market sector better than firms from developed economies. This, in and of itself, is a proprietary advantage. It is important to note that the advantages that multinationals from the developing world posses may, in many cases, be different from the ones that those from the developed world possess. This is mainly due to the difference in the sources of the monopolistic advantage in these firms. With some adjustments to the conceptualization of the sources of monopolistic advantages, the multinational theories can do a good job in providing insights into the motivations for outward investments from developing economies. Importantly, the size of the economy and its history of industrialization will impact on the types of multinational that emerge from these areas. Therefore, developing countries at different stages of their development life cycle will produce different types of multinationals.

Determinants of outward FDI from SIDS: The world investment report of 2006 outlined a number of reasons for the increased level of outward foreign direct investments from developing economies. Among them are: improved market and trade conditions, increased cost of production at home, changing industry conditions in the home market and, changing macroeconomic policy conditions in the home market.

Due to the increasing liberalization of world markets, tariff and non-tariff barriers to entry in developing countries are falling. This has resulted in increased competition and, consumers having greater choice for goods and services. With competition from both local and international firms, the markets in these developing economies, especially small economies are becoming saturated. Therefore, many firms in these markets are seeking customers outside their domestic environment.

The significant amount of inward foreign direct investments from developed to developing countries have resulted in an increase in the cost of labor in the latter. The rising labor cost significantly impacts on the production process of all firms in these developing economies. Therefore, it appears that these domestic firms have started to look for other developing economies where labor cost is lower, to engage in vertical foreign direct investment. The aim is to generate cost savings that can result in the firm remaining in business in the home market. The most likely counterfactual is that if the firm does not engage in this type of direct investment, it will have to go out of business since the cost of production would become too exorbitant due to the higher wage bill. Indeed, rising labor cost will have a significant impact on the cost structure of firms from developing economies, 
because a lot of their production processes are labor intensive.

Macro-economic policies in the domestic market and in the host market also influence the level of outward foreign direct investment from developing economies. For example, increased levels of privatization in most former communist countries in Eastern Europe have provided opportunities for investors from other mature, developing countries to purchase assets in these newly industrialized economies. Because these investors have the experience of operating in a developing country market, it gives them a competitive advantage that they can exploit in the newly industrialized economies ${ }^{[22]}$. Economic policies in the home market also influence the increased level of outward foreign direct investment from developing economies. Economic uncertainty brought about my macro-economic instability tends to force firms to look for markets in other geographical locations that are seen as stable. For example, an unstable exchange rate, high interest rate, high inflation rate among other things; all contribute to increased production cost in the home market. Because of the higher production cost, firms may engage in vertical foreign direct investment in order to gain cost savings on their production operation.

Generally, the answer to the determinant of FDI flows is sought through statistical analyses of economic, social, political and institutional factors ${ }^{[28]}$. The factors common in most studies are per capita income, per capita income growth rate, interest rate, literacy rate, corruption level and current account balance.

Per capita income is measured by the GDP per person in the population. In some cases, it is used as a measure for a country's market size, strength and degree of openness ${ }^{[23]}$. FDI is usually undertaken by home economies with some unique strengths such as sophisticated technology and some experience in FDI $^{[19]}$. GDP represents the level of development of a country. According to the investment-development path model ${ }^{[10]}$, it is a good predictor of the level of outward FDI. It is in this vein that GDP is an important determinant of outward foreign investment in this study.

Another determinant is the per capita income growth rate. This is proxied by the change in per capita over time. Like other researchers that look at the relationship between per capita growth rate and inward FDI flow ${ }^{[20]}$, this study expects a positive relationship with outward investment. The higher the economic growth rate, the more developed is the economy. According to the thesis of the investment development path model, as the economy becomes more developed, the higher will be the level of outward foreign direct investments.

The country's current account position, another determinant of outward foreign direct investment flow was proxied by the sum of balance on goods, services and income. Similarly, like Schneider and Frey ${ }^{[20]}$, this study expects a positive relationship between the country's current account and the level of outward foreign direct investment. The reasoning follows that of the investment-development path model where the logic is that, if the country's current account is in a surplus, this will correlate with a more developed nation. As such, with a higher levels of development in a country, the expectation is that there will be a higher level of outward foreign direct investment.

The level of interest rate applicable to private firms is also a critical determinant of the level of outward foreign direct investment. Like Agarwal $^{[3]}$ who identified that the higher the level of interest rate the lower will be the level of inward foreign direct investment, this study expects that with high interest rates in the home market, more firms will seek to operate in other locations. This is also consistent with the logic of the investment- development path model. In more developed markets, interest rates applicable to private investment are normally low thus encouraging firms to produce locally.

Besides economic factors, other researchers have also analyzed social factors such as literacy rate and corruption levels as determinants of foreign direct investment flow ${ }^{[7,28]}$. As for the level of literacy, it is expected that the higher the rate of literacy in the home economy, the least likely firms will want to invest abroad. This is in the opposite direction to Cheng and $\mathrm{Kwan}^{[7]}$ who found that literacy rate is positively related to inward investment. Similarly, it is expected that with a higher level of corruption in the home market, there should be a higher level of outward foreign direct investment. The proxy for the level of corruption is the transparency corruption index developed by transparency international. The inclusion of this variable in the study is important because corruption is a relevant issue in most small, island developing states. Table 1 below provides a summary of these variables, their proxies and their sources. 
Am. J. of Economics and Business Administration 1 (2) 47-56, 2009

Table 1: Regression variables

\begin{tabular}{|c|c|c|}
\hline Variables & Measurement & Data source \\
\hline $\begin{array}{l}\text { Outward FDI (We used FDI } \\
\text { per capita because it takes care } \\
\text { of difference in country size) }\end{array}$ & $\begin{array}{l}\text { Flows of direct investment capital out of the economy. This } \\
\text { includes, equity capital, reinvested earnings, financial } \\
\text { derivatives associated with intercompany transactions. } \\
\text { Captured as US\$ mill/population i.e., outward FDI per capita }\end{array}$ & $\begin{array}{l}\text { World investment report, } \\
\text { International financial statistics }\end{array}$ \\
\hline GDP per capita & $\begin{array}{l}\text { The sum of final expenditure per person in the } \\
\text { population (US\$) }\end{array}$ & $\begin{array}{l}\text { World economic outlook, International } \\
\text { financial statistics, world development } \\
\text { indicators }\end{array}$ \\
\hline GDP per capita growth rate & Change in per capita over time $(\%)$ & World development indicators \\
\hline Interest rate & Commercial bank lending rate $(\%)$ & International financial statistics \\
\hline Literacy rate & $\begin{array}{l}\text { Adult literacy rate i.e. population } 15 \text { years and older who } \\
\text { can, with understanding, read and write a short statement } \\
\text { about their everyday life }(\%)\end{array}$ & World development indicators \\
\hline Level of corruption & Transparency international corruption index & Transparency international \\
\hline Current a/c balance & $\begin{array}{l}\text { Sum of balance on goods, services, income. Measured as } \\
\text { percent of GDP i.e., Curr Bal US } \$ \text { mill/GDP }\end{array}$ & International financial statistics \\
\hline
\end{tabular}

\section{MATERIALS AND METHODS}

The research method: To motivate this research, some general framework that encompasses the relevant variables has to be established. We therefore write the general expression as:

$$
\mathrm{Y}_{\mathrm{ij}}=\int\left(\mathrm{X}_{1}, \mathrm{X}_{2}, \mathrm{X}_{3} \ldots \mathrm{X}_{\mathrm{n}}\right)+\varepsilon_{\mathrm{ij}}
$$

Where:

$\mathrm{Y}_{\mathrm{ij}} \quad=$ The dependent variable representing outward foreign direct investments per capital

I $=$ The year

$\mathrm{J}=$ The country

$X_{1} \ldots X_{n}=$ Represent vector of those variables that impact on the level of outward foreign direct investments. These include social, economic, technological, regulatory among others

$\varepsilon_{\mathrm{ij}} \quad=$ The error term

For an empirical study, researchers generally select those specific variables that are important to the question under investigation. The choice of variable will generally depend on the conceptual issue being investigated and the availability of data. Bearing these considerations in mind and given the difficulty of gaining data in developing countries, especially the smaller ones, this study has opted to use the economic and social variables since there is relatively more data available on those compared to technological or regulatory variables. With the specific variables chosen, some variant of the general model in 1 is estimated. In this case, the model estimated is ${ }^{[10,20]}$ :

$$
\begin{aligned}
\log \left(Y_{i j)}=\right. & \alpha+\beta_{1}\left(\log \mu_{1}\right)+\beta_{2} \pi_{2}+\beta_{3} \lambda_{3}+\beta_{4} \theta_{4} \\
& +\beta_{5} \delta_{5}+\beta_{6}\left(\log \phi_{6}\right)+\varepsilon_{i j}
\end{aligned}
$$

Where:

$\mu_{1}=$ GDP per capita

$\pi_{2}=$ GDP per capita growth rate

$\lambda_{3}=$ Interest rate

$\theta_{4}=$ Literacy rate

$\delta_{5}=$ Level of corruption

$\phi_{6}=$ Current $\mathrm{a} / \mathrm{c}$ balance

The degree of significance of the variables in the model will give an indication of the factors that are relevant in determining the level of outward foreign direct investment.

The research data: A five year panel data for the years 1998-2002 was used to estimate the theoretical model in 2 above. Data were collected on the six variables listed above for 15 small, developing economies. The list of countries used for data collection is highlighted in Table 2. It is important to note that this list is skewed towards Caricom countries because of the inability to get sufficient data on other SIDS. As such the SIDS in the table are not fully representative of all SIDS in the world. However, the most important point from this study is to get a snapshot of the factors that impact on outward FDI from SIDS. Future studies can look at a more comprehensive list of SIDS which would better aid in generalizing the results.

Statistical data for each country were collected from various sources including international financial statistics and world economic outlook published by the IMF, world development indicators published by the World Bank and, the world investment report published by UNCTAD, the trade arm of the United Nations. To build the panel, data for each variable were taken from various years of these publications. 
Am. J. of Economics and Business Administration 1 (2) 47-56, 2009

Table 2: List of SIDS

\begin{tabular}{ll}
\hline No. & Country \\
\hline 1 & Antigua \\
2 & Anguilla \\
3 & Aruba \\
4 & Bahamas \\
5 & Barbados \\
6 & Belize \\
7 & Cape Verde \\
8 & Dominica \\
9 & Dominica Republic \\
10 & Guyana \\
11 & Haiti \\
12 & Jamaica \\
13 & Mauritius \\
14 & Netherlands Antilles \\
15 & Trinidad and Tobago \\
\hline
\end{tabular}

\section{RESULTS}

The aim of this study was to understand the macroeconomic and social factors in the home environment which influence firms to make outward foreign direct investment. This study was done specifically in the context of small, developing economies because there is very little work on the motivations for the increased level of outward foreign direct investments from these economies. The results presented in this section will no doubt extend the empirical work in this area. Table 3 below highlights some descriptive statistics for the variables used in the study in order to provide insights into the nature of the SIDS that were used.

Further, to determine whether or not the variables are from a normal distribution, an important condition for using multivariate regression to provide reliable answers to the research question, efforts were made to plot the residual of the regression against the dependent variable. Figure 1 shows a normal distribution.

Results of the statistical analysis: From the multivariate regression, the results reveal that per capita income, per capita income growth rate (i.e., economic growth) and, the level of corruption in the home market are all factors that influence local firms to invest in foreign market through foreign direct investment. These results are shown in Table 4.

Further, to determine the stability of the coefficients of these significant variables, a restricted model was estimated. The analysis revealed that all the variables remained stable that is, none of the significant factors became insignificant. This suggests that the results are robust. Table 5 highlights these results.

Again, because of the exploratory nature of this work, we do not want to make predictions about the level of outward direct investments that will flow based on the model coefficients. The most important issue is to determine which factors influence the decision.
Table 3: Descriptive statistics for SIDS

\begin{tabular}{lrrr}
\hline Variables & Mean & Std. deviation & $\mathrm{N}$ \\
\hline Outward FDI/capita & 266.01 & 570.895 & 75 \\
GDP per capita US\$ & 11293.06 & 5129.516 & 75 \\
GDP per capita growth & 2.15 & 1.466 & 75 \\
Interest rate-bank lending & 15.11 & 7.420 & 75 \\
Adult literacy rate & 90.56 & 8.018 & 75 \\
Level of corruption & 5.24 & 1.376 & 75 \\
Current account balance US\$ mill & -217.33 & 408.207 & 75 \\
\hline
\end{tabular}

Table 4: Multivariate regression-determinants of outward FDI

\begin{tabular}{lrrl}
\hline Variables & Beta & \multicolumn{1}{c}{ T } & p-value \\
\hline GDP per capita US\$ & 0.118 & 4.136 & 0.000 \\
GDP per capita growth & -218.637 & -3.113 & 0.004 \\
Interest rate-bank lending & -23.399 & -1.417 & 0.166 \\
Adult literacy rate & -13.365 & -1.307 & 0.200 \\
Level of corruption & -3.513 & -2.565 & 0.015 \\
Current account balance & -0.374 & -1.933 & 0.062 \\
US\$ mill & & & \\
Constant & 2637.913 & 2.282 & 0.029 \\
R2 & 0.610 & & \\
Adjusted R2 & 0.550 & & \\
F-statistic & $8.8(0.00)$ & \\
\hline Dependent variable $=$ Outward FDI US\$ Mill/GDP. *: Variables \\
significant at the 5\% level of significance (p<0.05)
\end{tabular}

significant at the $5 \%$ level of significance $(\mathrm{p}<0.05)$

Table 5: Restricted multivariate regression model results

\begin{tabular}{lrrl}
\hline Variables & \multicolumn{1}{c}{$\mathrm{B}$} & $\mathrm{t}$ & $\mathrm{p}$-value \\
\hline GDP per capita US\$ & 0.116 & 4.300 & 0.000 \\
GDP Per capita growth & -200.450 & -2.809 & 0.008 \\
Level of corruption & -2.583 & -2.178 & 0.036 \\
(Constant) & 657.329 & 1.220 & 0.230 \\
R2 & 0.570 & & \\
Adjusted R2 & 0.520 & & \\
F-statistic & $11.6(00)$ & & \\
\hline
\end{tabular}

Dependent variable: Outward FDI US\$ Mill/GDP, $*=$ Variables that are significant

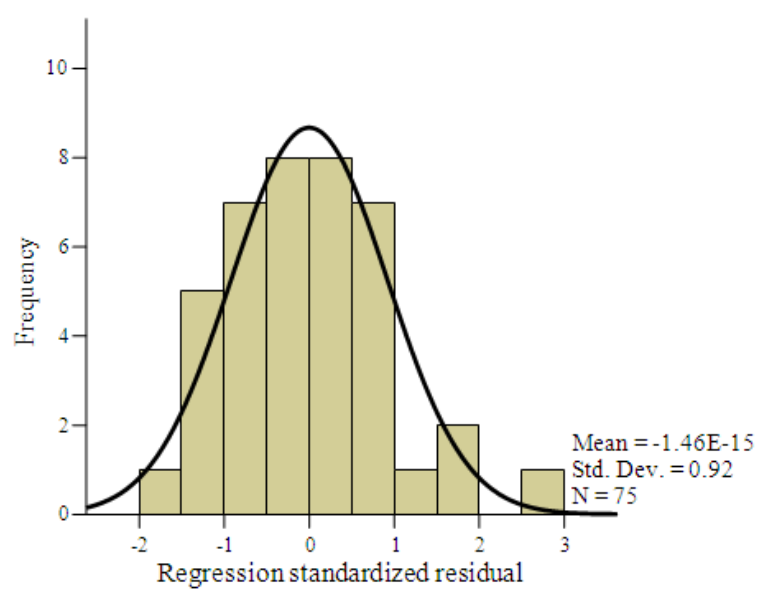

Fig. 1: Distribution of the independent variables

Further work should improve upon this study and make predictions about levels of outward investment when a more significant body of work is developed on this area in relation to SIDS. The discussion below will try to 
shed some light on the findings above and identify the implications of the work for managers in firms operating in small, developing countries and, government policymakers who are interested in getting more firms from their economy to engage in outward FDI. Indeed, FDI, whether inward or outward eventually benefits the home economy.

\section{DISCUSSION}

The results from the analysis of the multivariate model suggest that corruption level, per capita income and per capita growth rate are all important factors which influence firms from small economies to engage in outward foreign direct investment. An immediate look at these variables suggests that they adhere to the predictions from the investment-development path model. There are also practical rationale that can explain some of these results.

The model suggests for example, that the higher the corruption level at home the higher will be the level of outward investment. Because corruption is seen as a cost to doing business, if firms want to reduce their cost structure in order to compete effectively with both other domestic and international firms, they will have to find away to reduce this cost. Relocating production processes to areas that have a lower level of corruption will generate some cost savings for these firms. With corruption imposing an onerous cost on firms, without relocating to low corruption locations, the next alternative would possibly be for them to go out of business. However, the policy implications of this result are not very clear, because no government would want to keep the level of corruption high just to have increased outward FDI.

Also, the results suggest that if per capita income at home increases, the level of outward direct investment will decrease. The idea may be that with consumers in the home market getting richer, then there is no need to go abroad. The firm can exploit its advantages at home and still remain profitable. This would make sense only if the local market is not competitive, large enough to help firms to generate economies of scale in production and, the enabling environment is conducive for business operation. The implication for government policy is not very clear as well, because it is counter intuitive for governments to want to reduce the per capita income of their population.

On the other hand, if per capita income growth rate is increasing, that is, if the home economy is growing, the model suggests that the level of outward foreign direct investment will increase. Theoretically, this prediction follows that of the Investment development cycle hypothesis ${ }^{[10]}$. Intuitively, this result makes sense. If the home economy is becoming richer, but market size is small, firms will seek customers in other markets to sell their goods and services. Further, they will have the money to undertake setting up operations in foreign markets, which can be a costly Endeavour. The policy implications of this variable are much clearer than the corruption and per capita income variables. Clearly, if governments want to increase the amount of outward FDI from their economies, they will have to put policies in place that will grow the economy. The choice between supporting local investments at home and national firms to improve their international competitiveness by carrying out foreign direct investment, should not be seen as mutually exclusive. Indeed, outward direct investment is not a zero-sum game where jobs, productivity gains and skills are transferred from home to host economies. Both the home and the host country will benefit from this investment.

In some cases, outward investment can be seen as a job saver at home. Due to the high level of economic and social uncertainty in the home environment, the cost of operating a business in these SIDS becomes quite exorbitant. This therefore makes them uncompetitive in light of foreign competition. The alternative for going abroad is to go out of business. Therefore, outward direct investment will ensure that the firm continues to operate and jobs remain at home while new ones are created in the host market. Further, when some jobs are created abroad, especially simple jobs, there is a need for more high skilled jobs to be created at home in order to coordinate these jobs abroad. As such, home market can benefit from having more high skilled jobs in areas such as operations management and information technology.

Also, another important benefit of outward FDI is that it may boost the sales of the parent company if the activities are complementary and as such, creating more jobs at home. If the foreign affiliates use inputs from home in their production process, this will require increased output from the parent company as it will now have to supply both foreign and domestic markets. Assuming that there is no idle capacity in the plant, this increased supply will require the parent to employ more labor to produce the extra output.

In light of the aforementioned benefits, active outward foreign direct investment promotion should be pursued by government policymakers. However, it is not only government policymakers who should be interested in outward foreign direct investment but, managers and decision makers at the firm level as well. 
The increase in reciprocal trading areas across the globe will no doubt bring increased competition to all home markets. If firms are to survive, they will have to seek customers in other markets besides their own. For example, the Economic Partnership Agreement (EPA) between Cariforum (Cariforum comprises of the 15 member states of Caricom i.e., the Caribbean Community and the Dominican Republic) and the European Union (EU) will result in increased competition for Caribbean firms from European firms. Therefore, one clear implication is that Caribbean firms will have to start seeking customers outside their domestic market if they are to survive. To do this, it will require that managers in firms from the Caricom region incorporate effective and successful competitiveness strategies if they are to compete effectively in non-domestic markets. Some of these strategies will include product differentiation not necessarily derived from advanced technologies but from management processes, networks and the shared advantage that they have operated in small, developing markets before. Indeed, since there are a number of small, developing countries in Europe (examples of countries that easily come to mind are Cyprus, Georgia, Slovenia), these advantages would be helpful in giving Caricom firms a competitive advantage. Effective management strategies will no doubt be critical in helping firms to seize opportunities in international markets.

This study also has implications for scholars in the field of management strategy. With the rise in the level of outward foreign direct investments from SIDS, management scholars will have to revisit their theoretical arguments on firm strategy. They will have to build on the work of multinational theorists such as $^{[15,22]}$ who argue that competitive advantages lie not only in superior technologies but can be found in the processes and management hierarchies of the firm. The fact that firms from SIDS are operating abroad through direct investment and are doing so successfully, implies that they have been able to develop some monopolistic advantages outside of the use of superior technologies. Management theorists will have to take these nontechnological factors into consideration when trying to understand how firms derive competitive strategies for successful operations in international markets.

The results also have implications for future research on FDI from SIDS. Future work should look at the pattern of the investment in order to derive stronger conclusions about directionality of outward foreign direct investments from small, economies. Future researchers can look, for example, at the countries from which these investments are coming; the countries that they go to; the form the investments take; the portion that goes to niche markets in developed economies versus those that go to mainstream markets in these countries among other things. Also, future researchers should try to represent a larger number of SIDS in their study.

\section{CONCLUSION}

There is no doubt that if governments want to improve the standard of living of citizens, the promotion of outward foreign direct investment can be a useful tool to help achieve this goal. This is even more important in small economies where domestic markets are small and governments are negotiating reciprocal trading arrangements with other trading areas such as the one between the EU and Cariforum. The lack of outward investments may lead to firms going out of business due to intense international competition in the home market. Indeed, managers in domestic firms will have to start upgrading the capacity of their firms so that they can be ready to invest abroad. On the other hand, governments will have to articulate policies that are conducive to economic growth so that the domestic economy can grow and provide sufficient resources to firms for them to launch into foreign direct investments. Stimulating outward foreign direct investments from SIDS will have to involve both the private and public sectors in order to be successful.

\section{REFERENCES}

1. I. Alon and J.R. McIntyre, 2008. Globalization of Chinese Enterprises. Palgrave Macmillan, New York.

http://www.palgrave.com/products/title.aspx?PID= 278691

2. Agrawal, R.G., 1981. Third World Joint Ventures: Indian Experience. In: Multinationals from Developing Countries. Kumar, K. and M. Mcleod (Eds.). Lexington Books, Toronto, pp: 115-132.

3. Agarwal, J.P., 1980. Determinants of foreign direct investments: A survey. Weltwirtschaftliches Arch., 116: 739-777. http://ideas.repec.org/a/spr/weltar/v116y1980i4p73 9-773.html

4. Barrell, R. and N. Pain, 1999. Trade restraint and Japanese direct investment flows. Eur. Econ. Rev., 43: 29-45.

http://ideas.repec.org/p/nsr/niesrd/43.html

5. Berman, E., J. Bound and S. Griliches, 1994. Changes in the demand for skilled-labor within US manufacturing: Evidence from the annual survey of manufacturers. Q. J. Econ., 109: 367-397. http://ideas.repec.org/a/tpr/qjecon/v109y1994i2p36 7-97.html 
6. Brainard, S.L., 1997. An empirical assessment of the proximity-concentration trade off between multinational sales and trade. Am. Econ. Rev., 87: 520-544.

http://ideas.repec.org/a/aea/aecrev/v87y1997i4p52 0-44.html

7. Cheng, L.K. and Y.K. Kwan, 2000. What are the determinants of the location of foreign direct investment? The Chinese experience. J. Int. Econ., 51: 378-400.

http://linkinghub.elsevier.com/retrieve/pii/S002219 969900032X

8. Devereux, M.P. and R. Griffith, 1998. Taxes and the location of production: Evidence from a panel of US multinationals. J. Public Econ., 68: 335-367. http://econpapers.repec.org/article/eeepubeco/v_3a 68_3ay_3a1998_3ai_3a3_3ap_3a335-367.htm

9. Dunning, J.H., 1977. Trade, Location of Economic Activity and the Multinational Enterprise: A Search for an Eclectic Approach. In: The International Allocation of Economic Activity, Ohlin, B., P.O. Hesselborn and P.E. Wijkman (Eds.). Macmillian, London, pp: 395-418.

10. Dunning, J.H., 1981. Explaining Outward Direct Investment of Developing Countries: In Support of the Eclectic Theory of International Production. In: Multinationals from Developing Countries, Kumar, K. and M. Mcleod (Eds.). Lexington Books, Toronto, pp: 22 .

11. Stephen H. Hymer, 1976. The International Operations of National Firms: A Study of Foreign Direct Investment. Cambridge Mass, MIT Press, ISBN: 10: 0-262-08085-0, pp: 1-253.

12. Kalotay. K., 2004. Outward FDI from central and eastern European countries. Econ. Plann., 37: 141-172. http://ideas.repec.org/a/kap/ecopln/v37y2004i2p14 1-172.html

13. Krugman, P. and M. Obstfeld, 2003. International Economics: Theory and Policy. 9th Edn., AddisonWesley, New York, pp: 1-712

14. Krishna, Kumar. and M. G. Mcleod, 1981. Multinationals from Developing Countries. Lexington Books, Toronto, pp: 211.

15. Sanjaya Lall, 1983. The New Multinationals: The Spread of Third World Enterprises. John Wiley and Sons, New York, ISBN: 0471902411, pp: 1-268.

16. Giorgio Barba Navaretti and A.J. Venables, 2004. Multinationals in the World Economy. Princeton University Press, New Jersey, pp: 1-352

17. Navaretti, B.G. and D. Castellani, 2003. Does investing abroad affect performance at home? Comparing Italian multinational and national enterprises. Centro Study Luca d'Agliano Development Studies, Working paper 180. http://cepr.org/meets/wken/2/2303/papers/castellani.pdf
18. Michael E. Porter, 1990. The Competitive Advantage of Nations. Free Press, New York. pp: 896.

19. Petri, P.A., 1994. The regional clustering of foreign direct investment and trade. Trans. Corporat., 3: 1-24. http://www.unctad.org/en/docs/iteiitv3n3a2_en.pdf

20. Schneider, F. and B.S. Frey, 1985. Economic and political determinants of foreign direct investment. World Develop., 13: 161-175. http://ideas.repec.org/a/eee/wdevel/v13y1985i2p16 1-175.html

21. UNCTAD, 2006. FDI From Developing and Transition Economies: Implications for Development. United Nations, New York.

22. Wells, L.T.Jr., 1977. The Internationalization of Firms From the Developing Countries in Agmon. In: Multinational From Small Countries, Kindleberger, C.P. (Eds.). MIT Press, Cambridge MA., pp: 133-156.

23. Louis, T. Wells, Jr. 1983. Third World Multinational: The Rise of Foreign Investments from Developing Economies. MIT Press, London. http://www.foreignaffairs.com/articles/37526/willi am-diebold-jr/third-world-multinationals-the-riseof-foreign-investment-from-d

24. Wheeler, D. and A. Mody, 1992. International investment location decisions: The case of US firms. J. Int. Econ., 33: 57-76. http://ideas.repec.org/a/eee/inecon/v33y1992i12p57-76.html

25. White, E., 1981. The International Projection of Fims from Latin American Countries. In: Multinationals from Developing Countries, Kumar, K. and M. Mcleod (Eds.). Lexington Books, Toronto, pp: $155-186$.

26. Williams, D.A. and D., Deslandes, 2008. Motivation for service sector foreign direct investments in emerging economies: Insights from the tourism industry in Jamaica. The Round Table, 97: 419-437. http://www.informaworld.com/smpp/content conte $\mathrm{nt}=\mathrm{a} 793170391 \sim \mathrm{db}=$ all $\sim$ jumptype $=\mathrm{rss}$

27. Alvin G. Wint, 1995. Corporate Management in Developing Countries: The Challenge of International Competitiveness. Westport, Connecticut, Quorum Books, ISBN: 0899309291, pp: 221.

28. Alvin G. Wint, 2003. Competitiveness in small developing economies: Insights from the Caribbean. UWI Press, Kingston Jamaica, ISBN: 9766401322, pp: 234. 